\title{
MULTIMODAL TRANSPORT IN KOSOVO
}

\author{
UDK: 656. 022. 8 (497.115) \\ Primljeno: 10. IV. 2018. \\ Pregledni znanstveni rad
}

\begin{abstract}
Development of the classic branches of transport until after the year 1999 was a characteristic of economic policies in Kosovo, which came as a result of improper functioning of the market economy and non-application of modern technologies.

Despite the great importance that the multimodal transport has for Kosovo, till today initial steps have been taken with the approval of the sector strategy for the multimodal transport 2015-2025 by the Kosovo Government, respectively by the Ministry of Infrastructure. The aim of this strategy is to set priorities in terms of infrastructure, as well as in terms of legal regulation.

This paper addresses this topic in Kosovo for the first time, among other things notes the newly established circumstances in Kosovo after the war in 1999, which led to the change of policy development in the field of transport in order to adapt to the newly created circumstances and approximate with EU integration processes.
\end{abstract}

Key words: Multimodal transport, Kosovo, Ministry for Infrastructure, sector strategy

\section{INTRODUCTION}

Social and economic development in any country, including Kosovo, is a major concern that aims to improve the living standards of citizens - its citizens as a whole and the individual in particular.

Shipping as part and foundation of all national economies of the states and of all global economy in general, and that of the EU, in particular, is a determinant factor of economic development.

Development of transport classical branches in national states was a feature of the national economic policies of all countries in the century that we left behind, and that is why it was born the necessity to change and adapt to new circumstances, that are created as a result of the integration processes within the EU and beyond.

Contemporary development of science and technology in general, and that of transport in particular, sets new requirements, both in national and international level that affects the development of new forms of transport.

1 Ph.D. Nexhat Jashari, Professor at Kosovo Academy for Public Safety-Faculty of Public Safety 
In this context, multi-modal transport is increasingly taking place in national and international policies as a result of the application of new technologies and advanced transportation. In addition, there are numerous advantages in comparison with classical branches of transport, service, and quality, which will be addressed in this paper; there is also a special priority, which I will refer to as the ecological advantage because it largely preserves the environment. Taking into account the geographical extension of the Republic of Kosovo, railway and road network, construction of the highway Morinë - Merdare, which will be linked to the highway Durrës - Kukës - Morinë, through which not only Kosovo will be linked, but will also link other regional countries with Albanian seaports and with pan-European corridors. Kosovo should definitely build a new well-developed transportation system, which is very well interconnected with classical transport branches. Therefore, the national policies of traffic and transport should be coordinated and should stem from the economic development process and of the EU traffic, as the Kosovo integration in the EU is conditioned, inter alia, with the establishment of a new traffic and transport system. Thus, the creation and development of multimodal transport model is a prerequisite for connecting the transport system that will link the national transport trends with the EU conveyor (transport) system.

\section{ON GENERAL MULTI-MODAL TRANSPORT}

The technological revolution was undoubtedly an important factor for developments that occurred in all areas in the field of transport. In particular, these changes were expressed after the World War II, when the combined transport was at the genesis of its development. The rapid development of science, technology, outlines the necessity for further development of the traffic to the new needs in the national as well as in the international aspect. ${ }^{2}$

In 1966, the first ship container "Fairland" opened the front line of the container in the international aspect and this marked another transport system, which started to produce high-level results, by applying technological innovations. ${ }^{3}$

Conventional transport or unimodal transport of goods nowadays is used less and less, although earlier, this mode of transport was the main transportation in the systems of national and international transport. With the introduction and development of modern technologies of transport such as palletization, containerisation, RO-RO, LO-LO, RO-LO, LO-RO, FO-FO, Hucke-pack, and technologies of the bimodal transport, the conventional transportation of goods began to lose its importance, and left its dominant role in the multimodal transport. ${ }^{4}$

2 Prof. dr. Mehdi Hetemi, Kontejnerizimi i transportit si sistem integral dhe i përbërë, E drejta, nr. 1-4, Prishtinë, 2007, p. 35.

3 https://www.google.com/\#q=short+histori+of+contenierasation+fairland,

4 Gordana Nikolic, Multimodalni transport, Rijeka, 2000, pg. 13. 
Conventional transport, respectively unimodal transport was that type of freight that was transporting goods from one place to another, by using only the transport vehicle of only one transport branch.

This type of transport was done based on a transport contract and a single transportation document, and only one subject organized this type of transport.

The rights and obligations of participants in the conventional transport, respectively in the unimodal transport are regulated by national rules when dealing with national conventional transport, whereas the international conventional transport is regulated by international conventions.

In theory and practice, the following synonyms are used for combined and multimodal transport Integrated transportation, integral transport, inter-modal transport, direct transportation, combined transport, mixed transport, diverse transport, unimodal transport, multi-modal transport and so forth. ${ }^{5}$

According to Muller, the intermodal transport involves the transfer of only one unit load with transport means of different transport branches, where a single operator usually organizes the entire chain of multimodal transport. ${ }^{6}$

Bukold said that inter-modal transportation is not only a union of different forms of transport, but represents a branch with a right, the specific structure of organization and functioning. ${ }^{\text {? }}$

D'Este has concluded that the multimodal transport is a legal, commercial and management system for transportation of goods by door-door system, using more than one branch of transport. D'Este describes the nature of intermodalism more as a service than technology. ${ }^{8}$

Inter-modal transport system uses the advantages of standardization of transport units in order to reduce risk and increase efficiency in deliveries using ways, namely various branches of transport. ${ }^{9}$

Today in the world, in the general scientific, legal theory, national legislation and practice, of the majority of countries and in the international arena, denomination, namely the notion of multimodal transport is mostly used.

Multi-modal transport, as highlighted by the authors and renowned scholars of this field, has many advantages compared to classical transport, consisting not only

5 Marian Hoeks, Multimodal Transport Law f. 6, botuar nga Kluwer Law International, PO Box 316, Netherlands.

6 Muller, Gerhardt (1995) "Intermodal Freight Transportation, Third Edition, Lansdowne, VA: ENO Transportation Foundation and Intermodal Association of North America, USA, p. 239.

7 Steffen Bukold, (1993) "Logistics by Combined Transport: Barriers to Market Entry and Strategies of Main Suppliers", International Journal of Physical Distribution \& Logistics Management, Vol. 23 Iss: 4, pp. $24-34$.

8 Glen D'Este (1996), "An event-based approach to modelling intermodal foreight systems", International Journal of Physical Distribution \& Logistics Management, Vol. 26, No. 6, pp. 4-15.

9 Woxenius Johan. (1998), "Development of small-scale intermodal freight transportation in a systems context", Dissertation, Department of Transportation and Logistics, Chalmers University ofTechnology, Göteborg, Sweden. 
in practical matters, but also on the issue of legal aspects that regulate this area, and which deal with the rights and obligations of the contracting parties. ${ }^{10}$

Taylor claims that multimodal transport, known in the American legal literature as intermodal transport, is a key to increasing productivity and competitiveness in the industry of transportation of goods, preserving the environment since the multimodal transport ensures the efficient use of transport in every stage and thus reducing the rate of energy expenditure and pollution. ${ }^{11}$

International multi-modal freight due to its importance and complexity in national and international known economic systems is known as a composed system that is located in a particular country to the country of destination, which is in another state. The multi-modal transport operator organizes all this activity.

United Nations Convention on international multimodal transport of goods contains the basic features of multimodal transport, which are: ${ }^{12}$

The multi-modal transport operator and the consignee are located in two different states;

Transportation of goods is made by using at least two means of transport, i.e. in this transport participate at least two different branches of transport;

The entire transport operation is conducted on the basis of only one contract for multi-modal freight transport;

4. The entire process is arranged by the multi-modal transport operator;

5. Contract for multi-modal transport links the transporter with the sender of the goods;

6. Only one document is issued for the entire transport of goods;

Multimodal transport was developed by the modern transportation technologies such as palletization, containerisation, RO-RO, LO-LO, RO-LO, LO-RO, FO-FO, Huckpack and bi-modal technologies.

Researchers of the multi-modal transport field, say that multi-modal transport system encompasses three categories of functions, such as: load function for shipping, transport and the transfer function. ${ }^{13}$

These new forms of transport technologies are mostly used in multi-modal transport, although they can also be used in other types of transport.

10 Marian Hoeks, Multimodal Transport Law f.4 Kluwer Law International, PO Box 316, Netherlands.

1 J. Taylor, Remove barriers to intermodal Transportation and Distribution, MPM, 1993, fq.

12 Ivo Grabovac, Konvencija U.N. o multimodalnom prijevozu robe, 1980, s komentarom, Pravni fakultet sveučilišta u Splitu, svezak 17, 1981.

13 Johan Woxenius, Kenth R. Lumsden, System and functional requirements for Ro - Ro cassettes in multimodal transport. Paper for the conference RoRo 94, April 26-28, Gothenburg, Sweden.Published by BML Business Meetings Ltd, 2 Station Road, Rickmansworth, Herts. WD3 1QP, England. 
As a result of the development of modern technologies of transport RO-RO, LO-LO, RO-LO, LO-RO, FO-FO, Huckpack and bi-modal technologies, the multimodal transport becomes more important and also marks an increase of efficiency in the transportation of goods, and at the same time reduce the negative impacts on human health, environment and in nature.

Applications of the modern transport technologies mentioned above, however, have a special role and importance of economic development and with their application in the transport system of the Republic of Kosovo will help Kosovo to be quickly and easily linked to the European transport system.

\section{SHORT BACKGROUND OF THE MULTIMODAL TRANSPORT DEVELOPMENT}

The scientific literature states that the firs form of the multi-modal transport has begun in 1839, by Birmingham \& Railway, with the transfer of containers between rail wagons and carriages with horses. ${ }^{14}$

The multi-modal transport, which we know today, has boomed in the 60's of the last century, when it was greatly used by different European countries.

The contribution of the containers in the development of multi-modal transport some theorists call as container revolution. ${ }^{15}$

Maritime transport was the first branch, which originally was "captured" by containerisation and then the railway transport.

Among the countries where the multimodal transport was developed rapidly, and which had taken the inclinable place, was West Germany. In this country, many terminals for multmodal transport were built according to the plan of the former transport minister Georg Leber, which is otherwise known as the Leberit plan of the year 1967.

According to Leberit's plan, large financial investments were made for the development of multimodal transport, which amounted to 1 billion DM (equivalent to 500 million Euros), and 250 million DM (125 million Euros) were invested in the development of multimodal transport technologies. These investments had a large influence in the rapid development of multimodal transport in the former West Germany.

In the nineties, the eastern regions of Germany were fully integrated into the network, which required a major investment in the terminal device. The government's

14 Woxenius Johan: Inventory of transshipment Technologies in intermodal transport, International Road Transport Union, Goteborg, 1977 f 6, Woxenius Johan: Development of Smallscale Intermodal Freight Transportation in a Systems Context - Report 34 , Department of Transportation and LogisticsChalmers University of Technology S-412 96, Göteborg, Sweden, 1998, fq. 10.

15 Jose Angelo Estrella Faria,Uniform Law for International Transport at UNCITRAL: New Times, New Players, and New Rules, Texas international Law journal Vol. 44/277, fq. 290. 
plans for the period from 1996 to 2012 exceeded the amount of DM 4.1 billion for the construction of new terminals and the improvement of the old ones. The main aim was to increase the amount of goods being transported in multimodal transport.

The planned transport was from 30 million tons to 90 million tons per day by 2010. The government together with Deutsche Bank gave 400 million DM and DM 200 million in reserves, which enabled the construction of seven multimodal transport terminals with modern technologies. ${ }^{16}$

Denmark and its government have developed important programs to promote the development of international multimodal transport. Thus, by 1999 it had invested around 160 million NLG or 73 million Euros for the development of the terminals' network, and additional 20 million NLG or 9 million Euros were given for the promotion of the multimodal transport.

Netherlands is the country in which multimodal transportation found its wide expression, so the cargo terminals via land and water transport are being developed with unprecedented speed.

Rotterdam as the largest port container had already been transformed into the largest and most important multimodal port in Europe. Besides European countries, the US transportation department is very active, thus giving the system of the US carrier the multimodal character.

Law on International Surface Transportation Efficiency in $1991,{ }^{17}$ which includes and regulates the transport in all of its modes, encourages the multimodal transport. Multimodal transport is developed by using a budget of 155 billion dollars in the period from 1992 to 1997 , of which less than $1 \%$ is used only for projects related to the multimodal transport of goods in the first four years. As part of this law, the Congress established a national working group ${ }^{18}$ to explore the future of American multimodal transport. The Commission gave three recommendations: ${ }^{19}$

- The purpose of the federal policy of international multimodal transport,

- Investment increase in international multimodal transport and

- Restructuring of governmental institutions to support the international multimodal transport.

The latest recommendation is met with the reorganization of the department for transport, focused on problems associated with transport.

16 WoxeniusJohan:Inventory of transshipment Technologies in intermodal transport,International Road Transport Union, Goteborg,1977 f. 8. Woxenius Johan: Development of Small-scale Intermodal Freight Transportation in aSystems Context - Report 34, Department of Transportation and Logistics Chalmers University of Technology S-412 96, Göteborg, Sweden, 1998, fq. 11.

17 International Surface Transportation Efficiency Act/ISTEA/.

18 National Commission on Intermodal Transport.

19 Htpp//WWW.bts.gov/smart/cat/325TAN.html. 


\section{NATIONAL STRATEGY FOR MULTIMODAL TRANSPORT}

The development of multimodal transport in the South East European countries and in particular the one in Kosovo and Albania is closely linked with the development of the internal transport network of the neighbouring countries, that are candidates for EU integration and for the integration into the internal transportation network in Southeast Europe.

This connection is especially important for the improvement of links within the region and the integration of countries in political and economic system of the EU.

The traffic infrastructure in general in the countries of the region is below the European standards due to lack of investments and the fact that a part of it is damaged during the wars that occurred in recent years of the twentieth century in the territories of some of these states.

Regional countries should do more in order to meet, respectively, fulfil the European standards and thus lay the foundations of the development of multimodal transport infrastructure.

The state of traffic and transport system in the countries of the region (Albania, Bosnia and Herzegovina, Kosovo, Croatia, Montenegro, Macedonia) in different branches of traffic can be estimated that do not meet the European standards, although the road network of these countries is relatively well spread, but the density and quality are different.

Huge investments have been made in Albania, including studies for the development of multimodal transport and the importance of this transport to Albania and Kosovo.

Institute of Transport Studies (IST) has researched the matter and made concrete proposals on the development of multimodal transport, and considering the importance of the development of transport between the two countries AlbaniaKosovo, IST in its own study named as "Intermodal transport Albania - Kosovo - Albania ", has treated road corridors linking these two countries and the prospects of their economic development.

State institutions have paid special attention to transport, so the government of Albania has set as a key priority, for road infrastructure, the construction of the road Durres-Kukes-Morine and the completion of the north-south and east-west corridors (Corridor VIII).

In addition, for the Albanian government the construction of branches connecting the corridors with other national axes remains a priority, including here the improvement and development of cross border roads and tourism, as well as improvement of management and maintenance system of road infrastructure.

Implementation of these priorities, aims the development of road infrastructure, which integrates the country in the region and Europe as a prerequisite for ensuring 
economic growth and development in the whole country, and will strengthen designing and implementing capacities, thus aiming to achieve recognized standards.

In fulfillment of commitments stemming from the Stabilization and Association Agreement in the field of Road Transport, the Albanian government has prioritized the design of policy on facilitating the entry into the market of carriers. In support of this commitment, the legislation will be strengthened by the government to avoid unfair competition, and will strictly implement bilateral and multilateral agreements on road transport.

Also, the restructuring of the Albanian railway system is a priority of the Albanian Government in the field of railway transport. Continuous improvement of the legal framework, aiming at full compliance of its models with the European ones, improvement of economic performance management, reduction of operational costs, reduction of subsidies, improvement of railway infrastructure and renewal of the general inventory of vehicles by giving priority to regional import by trains are objectives that are expected to be realized over the medium term, in order for the priorities of the Albanian Government to be fulfilled.

The ultimate goal is the inclusion of the rail network in the regional railway networks: Corridor VIII and the regional railway network of high performance. ${ }^{20}$

Albania is a member of the Intergovernmental Organization of the International Railway Transport since 1984 (OTIF). On June $1^{\text {st }}, 1984$, Albania ratified the Convention concerning the International Railway Transport of the May $9^{\text {th }}, 1980$ (COTIF), and is a member of several conventions. A great Importance was given to maritime transport. On $10^{\text {th }}$ of May 2006, Albanian government adopted the National Transport Plan, which constitutes the basic document that will regulate all transport sub-areas, and even maritime transport (shipping).

Laws and regulations regulate activities in the field of maritime transport in Albania, which incorporate the principles of international acts and the EU legislation.

The gradual creation of a unique and connected space at both the national and regional level is one of the strategic objectives for the air transport sector. The Albanian government seeks to; efficiently implement projects that will increase the capacity of circulation and methods of attracting private capital in these services. A special attention will be paid to the rigorous implementation of the legal obligations arising from being a part of some conventions and relevant international agreements in the field of maritime transport. For regulating the air transport field, the Republic of Albania has issued legislation in line with national and EU legislation. In addition to what has been said, it is necessary to emphasize the fact that the Albanian Government has signed and approved in principle "The horizontal agreement with EU member states", which regulates and sets common criteria and standards of operation right in the field of air transport.

20 Republika e Shqipërisë, Këshilli i Ministrave, Plani kombëtar për zbatimin e marrëveshjes së stabilizim asocimit, Tiranë, qershor 2006. 
In addition, the multilateral agreement "On the establishment of a common aviation area between the Republic of Albania and EU countries" is signed. ${ }^{21}$

Kosovo has taken the necessary steps in the development of multimodal transport policies; steps that in the future should be empowered with comprehensive support from the state institutions, science, and other relevant factors.

Kosovo's government in November 2009 approved the strategy for multimodal transport and Action Plan through, which is planning the development of the transport sector by $2030 .^{22}$

It is necessary to increase institutional capacities for multimodal transport planning.

The development of multimodal transport strategy in the Republic of Kosovo is built on the basis of short-term, medium, and long term planning. ${ }^{23}$

\section{CONCLUSION}

Since the earliest times of human society, a special importance has been given to the issue of transport, because people have evaluated the importance of transport of people and goods.

The supply of goods in the most easiest and convenient way had and still has existential importance. The ceaselessly development of the transport has preoccupied the experts on this field, but even today, this issue still preoccupies the experts because they want to make the transport more efficient and profitable.

The economic importance of the development of these technologies in the world and in our country passes the context of transport, thus becoming one of the most important tasks in rationalizing the distribution of goods and the overall development of the economy.

The construction of the Highway Morinë - Merdare, which will be connected with the highway - Kukës - Morinë, known as the Street of Nation (Rruga e Kombit), which will connect not only Kosovo, but also the regional countries with seaports of Albania and with pan-European corridors, is additional proof that Kosovo must build a new transport system that is well developed and well interconnected with the branches of classical transport.

The Government of the Kosovo Republic has adopted the multimodal transport strategy, which is a base document for undertaking the actions towards the development of infrastructure capacities for the multimodal transport. In this direction, the Government, alongside with other countries that are in transition,

21 Republika e Shqipërisë, Këshilli i Ministrave, Plani kombëtar për zbatimin e marrëveshjes së stabilizim asocimit,m Tiranë, qershor 2006.

22 Vendimi i Qeverisë së Republikës së Kosovës, nr. 04/93 i datës 13.11.2009.

${ }^{23}$ Qeveria e Republikës së Kosovës, Plani i veprimit 2010 për implementimin e partneritetit evropian për Kosovën. 
is making a step forward in its efforts to take a greater care for the multimodal transport.

In this context, one can conclude that the construction and intellectual capacity building of human resources with specialized knowledge in this field, who could face the challenges arising from the new transport system, is essential. The establishment of a national institute for transport will have a tremendous importance for meeting the demands arising in the realization of our goals for the further development of the national strategy for multimodal transport as a precondition for EU integration.

\section{References}

Prof. dr. Mehdi Hetemi, Kontejnerizimi i transportit si sistem integral dhe i përbërë, E drejta, nr. 1-4, Prishtinë, 2007.

https://www.google.com/\#q=short+histori+of+contenierasation+fairland ,

Gordana Nikolic, Multimodalni transport, Rijeka, 2000.

Marian Hoeks, Multimodal Transport Law, botuar nga Kluwer Law International, PO Box 316, Netherlands.

Muller, Gerhardt (1995) "Intermodal Freight Transportation, Third Edition, Lansdowne, VA: ENO Transportation Foundation and Intermodal Association of North America, USA,

Steffen Bukold, (1993) "Logistics by Combined Transport: Barriers to Market Entry and Strategies of Main Suppliers", International Journal of Physical Distribution \& Logistics Management, Vol. 23 Iss: 4.

Glen D’Este (1996), “An event-based approach to modelling intermodal foreight systems", International Journal of Physical Distribution \& Logistics Management, Vol. 26, No. 6.

Marian Hoeks, Multimodal Transport Law f.4 publikuar nga Kluwer Law International, PO Box 316, Netherlands.

J. Taylor, Remove barriers to intermodal Transportation and Distribution, MPM, 1993.

Ivo Grabovac, Konvencija U.N. o multimodalnom prijevozu robe, 1980, s komentarom, Pravni fakultet sveučilišta u Splitu, svezak 17, 1981.

Johan Woxenius, Kenth R. Lumsden, System and functional requirements for Ro - Ro cassettes in multimodal transport. Paper for the conference RoRo 94, April 26-28, Gothenburg, Sweden.Published by BML Business Meetings Ltd, 2 Station Road, Rickmansworth, Herts. WD3 1QP, England.

Woxenius Johan: Inventory of transshipment Technologies in intermodal transport,International Road Transport Union, Goteborg,1977 .

Jose Angelo Estrella Faria,Uniform Law for International Transport at UNCITRAL: New Times, New Players, New Rules. http://www.zoominfo.com/p/Jos\%C3\%A9Faria/206915358 
Woxenius Johan: Development of Small-scale Intermodal Freight Transportation in aSystems Context - Report 34, Department of Transportation and Logistics Chalmers University of Technology S-412 96, Göteborg, Sweden, 1998,

International Surface Transportation Efficiency Act /ISTEA/.

National Commission on Intermodal Transport.

Htpp//WWW.bts.gov/smart/cat/325TAN.html.

Rules TEXAS INTERNATIONAL LAW JOURNAL VOL. 44/277.

Republika e Shqipërisë, Këshilli i Ministrave, Plani kombëtar për zbatimin e marrëveshjes së stabilizim asocimit Tiranë, qershor 2006.

Vendimi i Qeverisë së Republikës së Kosovës nr. 04/93 i datës 13.11.2009.

Qeveria e Republikës së Kosovës, Plani i veprimit 2010 për implementimin e partneritetit evropian për Kosovën 